\title{
Assessment on Effective Investment During Inflationary Period in Ethiopia
}

\author{
Biruk Tsegaw Yadete \\ Share Division, Berhan Bank S.C, Addis Ababa, Ethiopia
}

\begin{abstract}
The purpose of this study is to scope the best possibilities for allocation of investable funds during inflationary periods in Ethiopia. The findings are based on conversations with major stakeholders, by reviewing the literature into options and in consultation with financial scholars in Ethiopia. The study offers a menu of effective cash utilization, assesses their suitability for Ethiopia context and their feasibility in the light of financial sector developments in the country. The basic premise of this study is that ultimately what is of concern to an investor, whether a household or an institutional investor, is the real value of its investments in terms of purchasing power. The issue to be addressed is which investment strategy make sense in an economic environment in which a major factor (although certainly not the only one) to be considered is substantial uncertainty about the future level of the prices of those goods and services. By investment strategy I mean decisions about how to allocate investable funds among two major investment classes: Ownership Investments and Lending Investments. The chapter is organized as follows. I will first discuss why it is real or inflation-adjusted rates of return and their uncertainty which ought to be the main concern of investors. I will then present the factors that affect investment which will state the direct and indirect factors which impact the decision making of the investors, examine the real rates of return on the two investment categories. Finally, I will discuss the implications of my findings for individual and institutional asset allocation policies.
\end{abstract}

Keywords: Inflation, Investment, Bond, Stock and Real Estate

DOI: $10.7176 /$ RJFA/12-13-03

Publication date:July $31^{\text {st }} 2021$

\section{Introduction}

One of the greatest problems facing Ethiopian economy today is inflation which is persistently a complex, economic and social problem of the economy. Inflation has become a leading topic of discussion in Ethiopian families and other countries of the world. Government's inability to provide a lasting solution to this aroused a universal conviction that inflation is inevitable and created pessimism that government has no power to bring rising price (inflation) trend to an end. Inflation is not only a serious problem but also has a disquieting effect on the economic life, political system and the society as a whole. A situation where the value of money continues to depreciate in terms of value, there is the tendency for rising prices for available goods and services generally and such situation is being referred to as inflation. Inflation can be defined as continuous rise in prices of goods and services. Inflation simply means too-much money chasing few goods. Inflation in the country has become a threat to the Ethiopian economy particularly to investment and development.

Inflation is a sustained rise in overall price levels. Moderate inflation is associated with economic growth, while high inflation can signal an overheated economy.

Inflation poses a "stealth" threat to investors because it chips away at real savings and investment returns. Most investors aim to increase their long-term purchasing power. Inflation puts this goal at risk because investment returns must first keep up with the rate of inflation in order to increase real purchasing power. For example, an investment that returns $2 \%$ before inflation in an environment of $3 \%$ inflation will actually produce a negative return $(-1 \%)$ when adjusted for inflation.

If investors do not protect their portfolios, inflation can be harmful to fixed income returns, in particular. Many investors buy fixed income securities because they want a stable income stream, which comes in the form of interest, or coupon, payments. However, because the rate of interest, or coupon, on most fixed income securities remains the same until maturity, the purchasing power of the interest payments declines as inflation rises.

In much the same way, rising inflation erodes the value of the principal on fixed income securities. Suppose an investor buys a five-year bond with a principal value of Birr100. If the rate of inflation is 3\% annually, the value of the principal adjusted for inflation will sink to about Birr 85 over the five-year term of the bond.

Because of inflation's impact, the interest rate on a fixed income security can be expressed in two ways:

- $\quad$ The nominal, or stated, interest rate is the rate of interest on a bond without any adjustment for inflation. The nominal interest rate reflects two factors: the rate of interest that would prevail if inflation were zero (the real rate of interest, below), and the expected rate of inflation, which shows that investors demand to be compensated for the loss of return due to inflation. Most economists believe that nominal interest rates reflect the market's expectations for inflation: Rising nominal interest rates indicate that inflation is 
expected to climb, while falling rates indicate that inflation is expected to drop.

- $\quad$ The real interest rate on an asset is the nominal rate minus the rate of inflation. Because it takes inflation into account, the real interest rate is more indicative of the growth in the investor's purchasing power. If a bond has a nominal interest rate of $5 \%$ and inflation is $2 \%$, the real interest rate is $3 \%$.

Unlike bonds, some assets rise in price as inflation rises. Price rises can sometimes offset the negative impact of inflation:

- Equities have often been a good investment relative to inflation over the very long term, because companies can raise prices for their products/services when their costs increase in an inflationary environment. Higher prices may translate into higher earnings. However, over shorter time periods, stocks have often shown a negative correlation to inflation and can be especially hurt by unexpected inflation. When inflation rises suddenly or unexpectedly, it can heighten uncertainty about the economy, leading to lower earnings forecasts for companies and lower equity prices.

Prices for commodities generally rise with inflation. Commodity futures, which reflect expected prices in the future, might therefore react positively to an upward change in expected inflation.

\section{Overview of influential factors in investment}

Investment is an act of current spending for expected future return. It expands the productive capacity of a nation and plays a crucial role in the economic growth and development process. Investment has been regarded as one of the primary engines of growth (Wade, 1989, P. 71, UNCTAD, 2001, P. 1). There are a range of factors which influence the viability of any investments and these are discussed in this section.

\section{a. Interest rates (the cost of borrowing)}

Investment is financed either out of current savings or by borrowing. Therefore investment is strongly influenced by interest rates. High interest rates make it more expensive to borrow. High interest rates also give a better rate of return from keeping money in the bank. With higher interest rates, investment have a higher opportunity cost because you lose out the interest payments.

b. Economic growth (changes in demand)

Investors invest to meet future demand. If demand is falling, then firms will cut back on investment. If economic prospects improve, then firms will increase investment as they expect future demand to rise. There is strong empirical evidence that investment is cyclical. In a recession, investment falls, and recovers with economic growth.

c. Confidence/expectations

Investment is riskier than saving. Firms will only invest if they are confident about future costs, demand and economic prospects. Keynes referred to the 'animal spirits' of businessmen as a key determinant of investment. Keynes noted that confidence wasn't always rational. Confidence will be affected by economic growth and interest rates, but also the general economic and political climate. If there is uncertainty (e.g. political turmoil) then firms may cut back on investment decisions as they wait to see how event unfold.

\section{d. Technological developments (productivity of capital)}

Long-term changes in technology can influence the attractiveness of investment. If there is a slowdown in the rate of technological progress, investors will cut back investment as there are lower returns on the investment.

\section{e. Availability of finance from banks}

In many cases, banks were short of liquidity so had to cut back lending. Banks were very reluctant to lend to firms for investment. Therefore despite record low-interest rates, firms were unable to borrow for investment - despite firms wishing to do that. Another factor that can influence investment in the long-term is the level of savings. A high level of savings enables more resources to be used for investment. With high deposits - banks are able to lend more out. If the level of savings in the economy falls, then it limits the amounts of funds that can be channeled into investment.

\section{f. Others (depreciation, wage costs, inflation, government policy) \\ Inflation}

In the long-term, inflation rates can have an influence on investment. High and variable inflation tends to create more uncertainty and confusion, with uncertainties over the future cost of investment. If inflation is high and volatile, firms will be uncertain at the final cost of the investment, they may also fear high inflation could lead to economic uncertainty and future downturn. Countries with a prolonged period of low and stable inflation have often experienced higher rates of investment.

\section{Wage costs}

If wage costs are rising rapidly, it may create an incentive for a firm to try and boost labour productivity, through investing in capital stock. In a period of low wage growth, firms may be more inclined to use more labour-intensive production methods. 


\section{Depreciation}

Not all investment is driven by the economic cycle. Some investment is necessary to replace worn out or outdated equipment. Also, investment may be required for the standard growth of a firm. In a recession, investment will fall sharply, but not completely - firms may continue with projects already started, and after a time, they may have to invest in less ambitious projects. Also, even in recessions, some firms may wish to invest or startup.

\section{Public Sector investment}

The majority of investment is driven by the private sector. But, investment also includes public sector investment - government spending on infrastructure, schools, hospitals and transport.

\section{Government policies}

Some government regulations can make investment more difficult. For example, strict planning legislation can discourage investment. On the other hand, government subsidies/tax breaks can encourage investment. In China and Korea, the government has often implicitly guaranteed - supported the cost of investment. This has led to greater investment - though it can also affect the quality of investment as there is less incentive to make sure the investment has a strong rate of return.

\section{Potential forms of investment}

Investment can be referred to as an individual's or business's direct financial contribution to a venture, as opposed to borrowed money. Ethiopia is country with multitude cash hoarding society. Cash hoarding is defined as cash lying idle, not-being used for payments. Therefore this could be driven by the opportunity cost, precautionary motive, or other motives. Though Ethiopia has more than 15 private and state owned banks but the multitude are unbanked. Experts estimate that the amount of cash circulating informally in Ethiopia was more than that under circulation via banks. As most transactions in Ethiopia are still cash-based the informal sector has a substantial share in the economy. And for the purpose of this study we will consider the opportunity cost of cash hoarding, which will be calculated by considering the concurrent average inflation rate i.e. $13.83 \%$ compared with respective types of investments.

Inflation as major influential factor will have huge impact on the elements of investments. Element of investment are those which are common in investment activity. These are return, risk and time. Return refers to reward from investment which includes currently income, capital gain or losses and profits. Risk is the change when the expected or prospective again or profit less they expected outcomes is the degree of happiness of losses. Time is the important factor in investment is the time which offers different courses of action. As time move on analysis believe that conditions changes and investors revaluate expected return for each investment (Garagdhia and Babuks, 2003).

Investment types, or asset classes, that you can choose from each is based on with distinct characteristics risks and benefits. Once you are familiar with the different types of assets you can begin to think about piecing together a mix that would fit with your personal circumstances and risk tolerance.

\section{Defining the 2 Types of Investments}

\section{a. Ownership Investments}

Ownership is what comes to mind for most people when the word investment is batted around. These are the most volatile and profitable class of investment. The following are examples.

\section{i. Stocks/ Shares}

More broadly speaking, all traded securities, from futures to currency swaps, are ownership investments. Investors purchase them in order to share in the profits, or because they will increase in value, or both. Some of these investments, such as stocks, come with the right to a portion of the company's value. Others, such as futures contracts, come with the right to carry out a certain action that will benefit their owners. Owning stock means owning a portion of a company. It may be a miniscule stake, but its ownership. In Ethiopian stock market has not been allowed to exist as a formal institution, and there are only unregulated and fragmented dealer markets, which mainly exists in banking and insurance sector.

Shares are considered a growth investment as they can help grow the value of your original investment over the medium to long term. If you own shares, you may also receive income from dividends, which are effectively a portion of a company's profit paid out to its shareholders.

Illustrative example - return on share of two banks i.e. Berhan and Awash:

* \#Berhan Bank S.C: On 2017/18 budget year the bank has made 410 million ETB profit before taxes and has paid Birr 204 for whom has a share of Birr 1000.

For comparison:

\#if one hoards cash: On 2017/18 budget year the average inflation rate was $13.83 \%$. This means the one who hold cash of Birr 1,000 at home will diminish its value by Birr 138.30 due to the concurrent inflation. And the real value of the cash will be Birr 861.70. Thus holding cash of Birr 1,000 will incur loss of Birr 138.30 . 
\#if one purchase shares from Berhan Bank: On 2017/18 budget year the average inflation rate was 13.83\%. This means the one who purchase shares of Birr 1,000 from Berhan Bank, though its value is diminished by Birr 138.30 due inflation but his shareholding with the bank will get him a dividend payment of 20.4\% (Birr 204). And the real value of the money will be Birr 1,065.70. Thus purchasing share of Birr 1,000 from Berhan Bank will incur profit of Birr 65.70 regardless of the concurrent inflation.

Year 2017/18 return on holding Berhan Bank share, given Birr 1000 investment

\begin{tabular}{|c|c|c|c|}
\hline $\begin{array}{l}\text { Nominal value of } \\
\text { money }\end{array}$ & $\begin{array}{l}\text { Return on holding Berhan } \\
\text { Bank share }\end{array}$ & $\begin{array}{l}\text { Budget } \\
\text { inflation rate }\end{array}$ & $\begin{array}{l}\text { Real value of } \\
\text { money }\end{array}$ \\
\hline Birr 1,000.00 & $20.40 \%$ & $13.83 \%$ & Birr 1,065.70 \\
\hline
\end{tabular}

* \#Awash Bank S.C: On 2017/18 budget year the bank has made 1.49 Billion ETB net profit after taxes and has paid Birr 543 for whom has a share of Birr 1000.

For comparison:

\#if one hoards cash: On 2017/18 budget year the average inflation rate was $13.83 \%$. This means the one who hold cash of Birr 1,000 at home will diminish its value by Birr 138.30 due to the concurrent inflation. And the real value of the cash will be Birr 861.70. Thus holding cash of Birr 1,000 will incur loss of Birr 138.30 .

\#if one purchase shares from Awash Bank: On 2017/18 budget year the average inflation rate was $13.83 \%$. This means the one who purchase shares of Birr 1,000 from Awash Bank, though its value is diminished by Birr 138.30 due inflation but his shareholding with the bank will get him a dividend payment of 54.3\% (Birr 543). And the real value of the money will be Birr 1,404.70. Thus purchasing share of Birr 1,000 from Awash Bank will incur profit of Birr 404.70 regardless of the concurrent inflation.

Year 2017/18 return on holding Awash Bank share, given Birr 1000 investment

\begin{tabular}{|c|c|c|c|}
\hline $\begin{array}{l}\text { Nominal value of } \\
\text { money }\end{array}$ & $\begin{array}{l}\text { Return on holding } \\
\text { Awash Bank share }\end{array}$ & $\begin{array}{l}\text { Budget } \\
\text { inflation rate }\end{array}$ & Real value of money \\
\hline Birr 1,000.00 & $54.30 \%$ & $13.83 \%$ & Birr 1,404.70 \\
\hline
\end{tabular}

Your expectation of profit is realized (or not) by how the market values the asset you own the rights to. If you own shares in Awash Bank, the prime private bank in the country, and the company posts a record profit, other investors are going to want Awash shares too. Their demand for shares drives up the price, increasing your profit if you choose to sell the shares.

Of course, the value of shares may also fall below the price you pay for them. Prices can be volatile from day to day and shares are generally best suited to long term investors, who are comfortable withstanding these ups and downs.

In theory, a company's revenues and earnings should increase at a similar pace as inflation. This means the price of your stock should rise along with the general prices of consumer and producer goods. Larger companies tend to have a stronger relationship with inflation than mid-sized companies, and mid-sized companies have had a stronger relationship than smaller companies.

\section{ii. Business}

The money put into starting and running a business is an investment. Entrepreneurship is one of the toughest investments to make because it requires more than just money. Consequently, it is an ownership investment with extremely large potential returns.

By creating a product or service and selling it to people who want it, entrepreneurs can make huge personal fortunes. Yoadan Tilahun, founder of Flawless Events and one of the emerging entrepreneurs in the country, is a prime example. When it comes to starting and running a business during inflation, business owners can often increase price on the product and service when prices of inputs are rising, which can flow through to profits and investor distributions.

\section{iii. Real Estate}

Houses and apartments that are purchased to rent out or to resell are investments.

The house you live in is a different matter because it is filling a basic need. It fills a need for shelter. It may appreciate in value over time, but it shouldn't be purchased with the expectation of profit. Anything that declines in value with use is not an investment. It's an expense.

Many people purchases homes that on the assumption that those houses could soon be sold for much more, which is also considered as a growth investment because the price of houses and other properties can rise substantially over a medium to long term period.

However, just like shares, property can also fall in value and carries the risk of losses.

It is possible to invest directly by buying a property but also indirectly, through a property investment fund. Unlike bonds, fixed assets rise in price as inflation rises. Price rises can sometimes offset the negative impact of inflation: 


\section{iv. Precious Objects}

Gold and precious gemstones can be considered ownership investments, provided that these objects were bought with the intention of reselling them for a profit. Like any investments, they may rise or fall in value over time. Gold and gems have market values that fluctuate.

From the cold-eyed view of the investor, they also have costs. They must be insured and kept in pristine condition in order to retain their value.

\section{b. Lending Investments}

Lending money is a category of investing. The risks generally are lower than for many investments and, consequently, the rewards are relatively modest.

A bond issued by a company or a government will pay a set amount of interest over a set period of time. The only real risk is that the company or government will go bankrupt, in which case the bondholder may get little or none of the investment back.

\section{i. Savings Accounts}

A regular savings account is an investment. The investor is essentially lending money to the bank. The bank will pay interest to the account holder and will earn its profit by loaning out the rest of the money to businesses at a higher rate of interest. Inflation can shrink your savings even if you've secured your funds in a savings account with an average interest rate.

In theory, when you're working, your earnings should keep pace with inflation. When you're living off your savings, inflation diminishes your buying power. In Ethiopia, interest rates decisions are taken by Monetary Committee of the National Bank of Ethiopia. The official rate is the bank's savings rate. The benchmark interest rate in Ethiopia was last recorded at 7 percent.

Year 2017/18 return on saving in bank, given Birr 1000 saving

\begin{tabular}{|c|c|c|c|}
\hline Nominal value of money & Saving interest rate & Budget year inflation rate & Real value of money \\
\hline Birr $1,000.00$ & $7 \%$ & $13.83 \%$ & Birr 931.70 \\
\hline
\end{tabular}

\section{Conclusion}

The impact of inflation on investments depends on the investment type. For investments with a set annual return, like regular bonds or bank certificates of deposit, inflation can hurt performance - since you earn the same interest payment each year, it can cut into your earnings. If you receive a payment of Birr1000 per year, for instance, that payment would be worth less and less each year given inflation.

In Ethiopia some people who do not like taking risks may not like this, but the truth still remains that during periods of rapid inflation, the value that money has can greatly reduce within a short period of time. One way to deal with this is by spending the money. Why not invest in the bank share now and get more shares now rather than later. Letting your money to sit will you cost you more in the long-run.

Despite the limited asset allocation options, due to restricted financial system, in the country; the study has assessed the possible effective investments given the available options.

During periods of inflation, equity investors experience fewer effects because during such periods, companies will usually increase the price tag on their products/services in response to increasing cost of production. Due to this, the profit that the company makes will increase. As a result, company earnings may have the potential to keep up with inflation, all things being constant but there can be no guarantee of this; as some companies may fail in inflationary times. If you are considering investing in the share market, remember that the value of the shares that you buy can fall as well as rise and you could get back less than you invested. For stocks/shares, inflation can have a mixed impact. Inflation is typically high when the economy is strong. Companies may be selling more, which could help their share price. However, companies will also pay more for wages and other cost, which hurts their value. Whether inflation will help or hurt a share can depend on the performance of the company behind it.

During the time period when someone is holding a bond, he or she will receive a fixed rate of interest, known as the coupon, and when it matures, those who invested when the bond was first issued should get their original capital back. You should however note that there is a probability that you can lose out on your investment. If the issuer gets into financial trouble, it could fail to meet its interest payments or even repay your capital. If that happens, you could get back less than you invest or even nothing at all. Usually, bonds are considered as being a lower risk venture when compared to stocks and they also offer a relatively steady and predictable income, though some bonds do carry higher risk than some shares. If your intention for investing in bonds is to avoid the undesirable effects of inflation, then you will need to find a portfolio that offers a higher earning potential than the current cost of living. It goes without saying that the higher the return a bond offers, the higher the risk involved.

On the other hand, precious metals like gold historically do well when inflation is high. As the value of the dollar goes down, it costs more dollars to buy the same amount of gold. If you have some spare amount of money (that is not your emergency fund), you should consider converting them to precious metal in order to save 
them from inflation. Again, during times of economic uncertainty, it's best to keep your wealth where you can directly control it - as local as possible. So which of the various precious metals is the best to invest in? Silver and gold have over the years shown that they can hold their value and sometimes even increase in value relative to paper money. And in the worst case scenario of economic collapse, gold and silver can become money again.

Real estate is a well-known investment that has proven to be able to withstand the effects of inflation. Unlike others, housing assets rise in price continuously as inflation rises. Price rises can sometimes offset the negative impact of inflation. This is because home values and rental incomes both tend to keep pace with inflation, making real estate a strong contender for this type of goal.

In conclusion, inflation is sometimes called the worst type of tax because you may not even notice it as it happens. Hypothetically speaking, earning four percent in a savings account while inflation grows at seven percent makes many feel four percent richer, while in fact they are three percent poorer. There is no need to bury your money in a field and there is no need to live in constant fear of an economic collapse. There are a lot of investment strategies that can allow you to escape the undesirable effects of inflation and economic collapse.

Diversifying your portfolio with exposure to share and real estate assets may help you shield your money against inflation. However, diversification and asset allocation do not protect against losses or guarantee returns. Inflation might be beyond your control, but that doesn't mean you can't take actions to help preserve your investments and savings from its effects. All you have to do is to choose an investment that aligns with your goals and level of risk tolerance, monitor its performance, and seek outside assistance if needed. You can battle inflation without exposing yourself to undue risk. Keep your money on a leash and don't let it run away from you.

\section{References}

$\rightarrow$ Bodie, Z., and Rosansky, V. 1980. Risk and Return in Commodity Futures. Financial Analysts Journal. May/June.

$\rightarrow$ Brainard, W. C; Shoven, J. B.; and Weiss, L. 1980. The Financial Valuation of the Return to Capital. Brookings Papers on Economic Activity 2: 453-502.

$\rightarrow$ Sathyanarayana, S., Gargesa, S. (2018). An Analytical Study of the Effect of Inflation on Stock Market Returns. IRA-International Journal of Management \& Social Sciences (ISSN 2455-2267), 13(2), 48-64. doi:http://dx.doi.org/10.21013/jmss.v13.n2.p3.

$\rightarrow$ Emrta, A. (2013), Inflation and Economic Growth: An Estimate of the Threshold Level of Inflation for Ethiopia, Addis Ababa, Ethiopia: Ethiopian Economic Association (EEA).

$\rightarrow$ Tamerat Kahssay (2017), Determinants of inflation in Ethiopia, journal of economics and sustainable development, vol 8, no. 19.

$\rightarrow$ Annual Report: National Bank of Ethiopia Annual Report, Fiscal year 2017/2018.

$\rightarrow$ Ashagrie Demile (2015), Inflation - Growth Nexus in Ethiopia: Evidence from Threshold Auto Regressive Model, Journal of economics and international finance, Vol 5(6), pp. 248-257.

$\rightarrow$ MOFED (2015), Macro economic developments in Ethiopia, Addis Abeba, MOFED, annual report.

$\rightarrow$ Abis Getachew Makuria (2013), the relationship between inflation and economic growth in Ethiopia, the University of Sydney, Australia.

$\rightarrow$ US National Bureau of Economic Research. The Changing Roles of Debt and Equity in Financing U.S. Capital Formation; Investment Strategy in an Inflationary Environment, Zvi Bodie [online].Available: http://www.nber.org/chapters/c11394 [p. 47 - 64]

$\rightarrow$ Dr. Gizachew Made (EEA member), Beyene Gebremeskel, and Tewodros Tiku 